Journal of Southeast Asian

\title{
Appendix C: Focus Group Summary of the Cambodian Student Association
}

Darlene Ly

University of California, San Diego, dbly@ucsd.edu

\section{Recommended Citation}

Ly, Darlene (2011) "Appendix C: Focus Group Summary of the Cambodian Student Association," Journal of Southeast Asian American Education and Advancement. Vol. 6 : Iss. 1, Article 4.

DOI: $10.7771 / 2153-8999.1020$

Available at: https://docs.lib.purdue.edu/jsaaea/vol6/iss1/4

This document has been made available through Purdue e-Pubs, a service of the Purdue University Libraries. Please contact epubs@purdue.edu for additional information.

This is an Open Access journal. This means that it uses a funding model that does not charge readers or their institutions for access. Readers may freely read, download, copy, distribute, print, search, or link to the full texts of articles. This journal is covered under the CC BY-NC-ND license. 


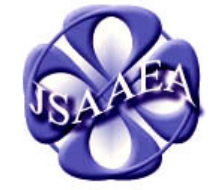

Volume 6 (2011)
Journal of Southeast Asian American Education \& Advancement

WWw.JSAAEA.org
A peer-reviewed scholarly journal published by the National Association for the Education \& Advancement of Cambodian, Laotian, and Vietnamese Americans (NAFEA)

\title{
Southeast Asian American Education 35 Years After Initial Resettlement: Research Report and Policy Recommendations
}

Conference Report of the National Association for the Education and Advancement of Cambodian, Laotian, and Vietnamese Americans

\section{APPENDIX C}

\section{Focus Group Summary of the Cambodian Student Association}

\author{
Darlene Ly \\ University of California, San Diego
}

Participants: All the students that took part in this open discussion came from different school experiences. Seven students in all took part in the discussions.

\section{Southeast Asian Student Education (K-12): Access, Assessment, and Accountability}

The majority of students expressed that their schools segregated students. Cambodians were a minority group. SEA students were seen around school in one location and did not really branched out. Southeast Asian students were also stereotyped under the "model minority myth" as "smart Asians" and tend to be labeled and misunderstood as "Chinese" and "Asian" as their ethnicity. Therefore, most of the SEA students agreed that they felt very isolated during their K-12 education because they either went to schools in areas where their race was not known or they had little connections to other students at their schools. With a few exceptions, one student participant shared that elementary, kindergarten programs that grouped students of immigrant families such as, Cambodians in a separate class was helpful because students had a different schedule that targeted according to their level of progress. These programs also benefited immigrant parents in adjusting to the American culture and better understand the U.S. educational school system.

Programs in ESL, ELL, etc. promoted reading, pronunciation and grammar, but they were less helpful in that it made SEA students fee "weird" and alienating because they were 
distanced from the rest of the class. Some students felt misplaced and expressed that their improvement in English was of personal growth rather than the curriculum. Students of ESL and ELL classes were also viewed differently and stereotyped in schools, especially those students who carried a foreign accent in their English.

Through K-12, all SEA student participants shared that they had none or very little experience in learning about SEA history. Students emphasized that there needs to be changes in World History curriculum to include SEA History because it is extremely underrepresented and leaves many students not knowing about their history, culture, identity and background.

\section{Southeast Asian Language and Culture Programs}

Overall, students showed interest in taking SEA language classes if they were available to them and counted for course credit. Some of the Cambodian students identified either strongly or partially about their connectedness to their SEA culture and identity. Students shared that they learned their language, culture, history and traditions from their parents, grandparents and other people. Most of the students admitted that they could not read or write. Some students could barely understand and speak the language, but a few that could speak the Khmer language conversationally expressed that speaking the language at home with their parents/grandparents, and other people outside the family generally benefited them.

\section{Southeast Asian American Higher Education Access and Opportunities}

Some of the challenges that these SEA or their peers faced in getting into college included: financial issues, lack of knowledge of birth control, lack of information and guidance, about applying for college/financial aid/fee waivers, mastering the English language, competition, gangs, violence and drugs. Students identified that SEA students are faced with financial dilemmas even with financial aid, they could not afford to go to a University or UC school because of lack of funds and resorted to City College or technical institute. Some girls did not have any knowledge of birth control and were pregnant before graduating high school, and ended up ruining their career goals and opportunities. English language was also difficult and acted as a barrier for many SEA students. Some students excelled in subjects except English and this prevented them from getting accepted to higher education at University schools. Gangs, violence, and drugs was also an issue in low-income communities that was influenced by their financial needs and living environments.

Some of the biggest problems that Southeast Asians are facing in their communities, students identified: financial stability lack of SEA adult knowledge, language barrier, alcohol and gambling that all stress more family problems. Financial stability, due to the horrendous budget deficit, high unemployment rate, and economy recession, SEA are faced with more troubling living conditions and costs. In addition, parents' lack of knowledge, education and involvement creates gaps and cultural clashes between son/daughter and parents at home. Language barriers also create misunderstandings and prevent SEA older adults from taking advantage of resources that are available to them, such as health care 
benefits. Furthermore, Southeast Asians' parents addiction to alcohol and or gambling is a huge problem, because when the parents are not at home to support their child, the child does not have any good role models to look up to, which can create all sorts of family problems and stress.

In turn, the Cambodian students identified that family problems are the root problems and that greater measures needs to be taken to help SEA families. Students felt that teachers/schools need to implement more programs that focus on the student's progression of learning so that they will be able to master the English language. They also supported for more SEA history and language classes to increase awareness and preserve SEA history, culture and identity. In addition, students felt that better Human Resource centers are needed in low-income SEA communities so that SEA people can have a place to go to get peer group support and more information about birth control pills and so forth. Also, SEA youth need access to afterschool learning programs or extracurricular activities such as, reading, sports, dance, music which, can get the youth off the streets and prevent them from negative influences. More so, schools and teachers should be more proactive in contacting SEA parents to get involved in their child's education. Students also felt that the school culture, teacher, staff need to be more optimistic and supportive of students of different cultural backgrounds. They felt that SEA students and parents needed to feel comfortable in going to the school and working with the teachers, rather than being intimidated by them.

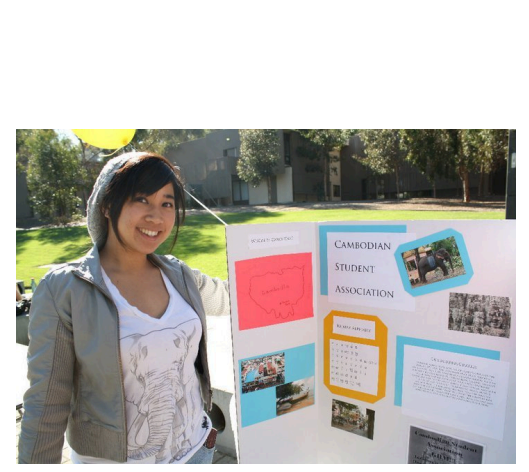

\begin{abstract}
About the Author
Darlene is currently a 4th year student at the University of California of San Diego majoring in Human Development. She has been actively involved in the Cambodian Student Association CSA throughout her college career and is passionate in bringing Khmer cultural awareness to her community. Recently, she has co-chaired K-12 Education for the Southeast Asian Intercollegiate Summit at UC Merced and
\end{abstract} served as a mentor for high school students, as part of SASC at UC Berkeley. Her passion is in education. She enjoys volunteering in low-income communities to provide students the access, guidance and support that they need to help them go further in their educational careers and believes that dreaming big comes with a bonus. 